\title{
IMPLEMENTASI VIEWBOARD DALAM MENDUKUNG PENYEBARAN INFORMASI DENGAN PENYAJIAN ARTIFICIAL INFORMATICS PADA PERGURUAN TINGGI
}

\author{
Untung Rahardja ${ }^{1}$ \\ Deddy Pratama ${ }^{2}$ \\ Ely Susanti ${ }^{3}$ \\ Alumni Universitasi Indonesia Program Studi Magister Teknologi Informasi ${ }^{1}$, Mahasiswa STMIK \\ Raharja Jurusan Teknik Informatika ${ }^{2}$, Alumni STMIK Raharja Jurusan Teknik Informatika ${ }^{3}$ \\ Email: untung@raharja.info,deddy.pratama@raharja.info,elysusanti@raharja.info
}

Diterima: 4 Juli 2016/ Disetujui : 18 Juli 2016

\begin{abstract}
Information Technology (IT) has been able to made improve the effectiveness, efficiency, competitiveness, and support the managerial activities of the organization. Here are discussed about the implementation of Viewboard application for an educational institution as a module assistant of leadership in making strategic decisions. Viewboard applications developed based on existing databases on other systems as a data warehouse. In the implementation, the Viewboard applications built using the PHP programming language for the front-office interface with the concept of Artificial Informatics as a result of the processed grain database query. The Viewboard application has been tested for statistical measure of student overview on Higher Education Academic Raharja as a development and research Viewboard done. The final results show that the test can pull Viewboard processed data from an existing repository database and display the information is critical to the presentation of the characteristics of Artificial Informatics.
\end{abstract}

Keywords: Viewboard, database, Artificial Informatics, critical

\section{ABSTRAK}

Kemampuan Teknologi Informasi (TI) telah dapat meningkatkan efektivitas, efisiensi, daya saing, dan mendukung kegiatan manajerial organisasi. Di sini dibahas tentang penerapan aplikasi Viewboard untuk institusi suatu pendidikan sebagai modul pembantu pimpinan dalam membuat keputusan strategis. Aplikasi Viewboard dikembangkan berdasarkan database yang sudah ada pada sistem yang lain sebagai data warehouse. Dalam penerapannya, aplikasi Viewboard dibangun menggunakan bahasa pemrograman PHP untuk front-office interface dengan konsep Artificial Informatics sebagai hasil sajian dari olahan query database. Aplikasi Viewboard telah diuji coba untuk mengukur statistik overview kemahasiswaan pada Perguruan Tinggi Raharja sebagai tempat pengembangan dan penelitian Viewboard dilakukan. Hasil akhir pengujian menunjukkan bahwa Viewboard dapat menarik olahan data dari berbagai repository database yang sudah ada dan menampilkan informasi bersifat critical dengan penyajian karakteristik dari Artificial Informatics.

Kata kunci: Viewboard, database, Artificial Informatics, critical

\section{PENDAHULUAN}

Dengan perkembangan kemajuan teknologi informasi, kebutuhan akan informasi yang akurat sangat dibutuhkan dalam kehidupan sehari-hari, sehingga informasi akan menjadi suatu elemen yang penting dalam perkembangan masyarakat saat ini dan untuk waktu mendatang. Namun kebutuhan akan informasi yang tinggi kadang tidak diimbangi dengan penyajian informasi yang memadai, sering kali informasi tersebut masih harus di gali ulang dari data yang tentunya jumlahnya sangat besar.

Kemampuan teknologi informasi untuk mengumpulkan dan menyimpan berbagai tipe data jauh meninggalkan kemampuan untuk menganalisis, meringkas dan mengekstrak pengetahuan dari data. Metode tradisional untuk menganalisis data 
yang ada, tidak dapat menangani data dalam jumlah besar. Pemanfaatan data yang ada di dalam suatu sistem informasi untuk menunjang kegiatan pengambilan keputusan, tidaklah cukup hanya mengandalkan data operasional saja, diperlukan suatu analisis data untuk menggali potensi-potensi informasi yang ada.

Para pengambil keputusan berusaha untuk memanfaatkan gudang data yang sudah dimiliki untuk menggali informasi yang berguna, dalam hal ini untuk membantu mengambil keputusan. Hal ini mendorong munculnya cabang ilmu baru untuk mengatasi masalah penggalian informasi atau pola yang penting atau menarik dari data dalam jumlah besar, yang disebut dengan data mining. Penggunaan teknik data mining diharapkan dapat memberikan pengetahuan-pengetahuan yang sebelumnya tersembunyi di dalam gudang data sehingga menjadi informasi yang berharga.

Perguruan tinggi saat ini dituntut untuk memiliki keunggulan bersaing dengan memanfaatkan semua sumber daya yang dimiliki. Selain sumber daya sarana, prasarana, dan manusia, sistem informasi adalah salah satu sumber daya yang dapat digunakan untuk meningkatkan keunggulan bersaing. Sistem informasi dapat digunakan untuk mendapatkan, mengolah dan menyebarkan informasi untuk menunjang kegiatan operasional sehari-hari sekaligus menunjang kegiatan pengambilan keputusan strategis.

Perguruan Tinggi Raharja sebagai salah satu instansi atau lembaga pendidikan yang bergerak di bidang TI (Teknologi Informasi) yang terus melakukan pembaruan dalam menciptakan wadah sistem informasi untuk kebutuhan sehari-hari. Namun mengingat semakin meningkatnya kebutuhan mahasiswa, maka informasi yang dibutuhkan pun semakin meningkat khususnya mengenai media yang disampaikan dan media yang digunakan untuk penyebaran informasi, sehingga kualitas dan kuantitas sistem yang berjalan saat ini jauh lebih baik.

Di dalam Surat Keputusan Direktur Perguruan Tinggi Raharja tahun 2009 Nomor: 772/SK-IMPLEMENTASI/PT/XI/2009,

berisikan tentang penggunaan email dalam penyebaran informasi sebagai jalur komunikasi resmi di lingkungan Perguruan Tinggi Raharja. Berdasarkan data pada yang ada saat ini, diinformasikan mengenai daftar pengguna email, dalam hal ini Rinfo, secara keseluruhan tanpa melihat status dari masingmasing mahasiswa tersebut. Hal ini tentu menunjukkan bahwa penyebaran informasi saat ini terbilang masih belum optimal dan tepat sasaran. Oleh karena itu, sebagai salah satu Perguruan Tinggi yang bergerak di bidang komputer harus selalu berinovasi untuk meningkatkan kualitas dari penyebaran informasi. Salah satu caranya ialah dengan mewujudkan sistem aplikasi monitoring Viewboard.

Viewboard merupakan sistem aplikasi yang menampilkan informasi dalam bentuk panel yang sangat penting bagi pemimpin institusi pendidikan (yang dapat di-analogikan di sini sebagai driver organisasi) dalam mengendalikan dan membawa organisasinya mencapai sasaran, tujuan, visi dan misi yang telah ditetapkan.

\section{PERMASALAHAN}

Dalam sistem informasi yang berjalan pada Perguruan Tinggi Raharja saat ini, beberapa output-nya diketahui masih berbentuk laporan sistem informasi yang ditampilkan dalam bentuk tabel dan data angka, belum dalam bentuk Viewboard.

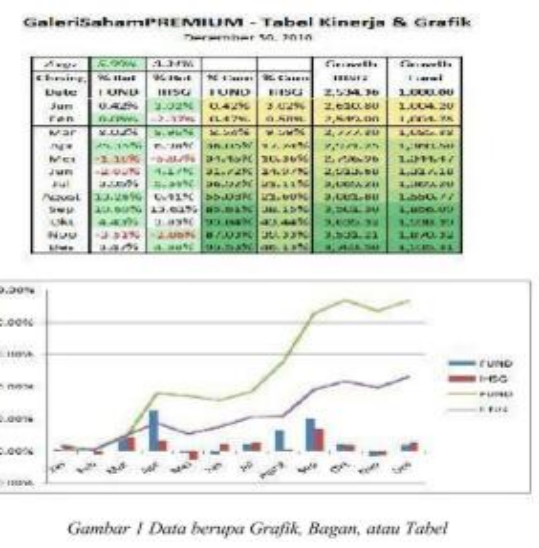

Penampilan informasi seperti ini memunculkan kendala tentu bagi pimpinan karena membutuhkan waktu yang tidak sedikit untuk memahaminya. Hasil sajian yang dipaparkan juga menghasilkan begitu banyak data angka yang sedemikian berlimpah, menjadikan data dan informasi tidak mudah dipantau, dan memberikan kesulitan dalam menarik olahan data dan informasi yang bersifat critical. 
Di sisi lain, pimpinan membutuhkan akses terhadap informasi strategis, dan informasi yang menyoroti penyimpanganpenyimpangan dari informasi tersebut. Karena itu, penelitian ini bertujuan untuk membuat serta menguji aplikasi Viewboard sebagai solusi yang efektif untuk memecahkan permasalahan dan kendala tersebut.

\section{METODE PENELITIAN}

Dalam melakukan penelitian ini penulis menggunakan dua metode, yaitu:

1. Observasi

Adalah metode pengumpulan data melalui pengamatan atau peninjauan secara langsung di lapangan atau lokasi penelitian. Penelitian ini dilakukan pada Perguruan Tinggi Raharja yang menjadi lokasi penelitian guna memperoleh data dan keterangan yang berhubungan dengan jenis penelitian.

2. Tinjauan Pustaka

Adalah segala upaya yang dilakukan oleh peneliti untuk memperoleh dan menghimpun segala informasi tertulis yang relevan dengan masalah yang diteliti. Pada metode ini penulis mendapatkan informasi dengan mempelajari buku-buku dan literature yang ada. Pada metode ini penulis akan mendapatkan informasi dengan mempelajari buku-buku dan literature yang ada seperti CCIT Journal Perguruan Tinggi Raharja.

\section{TINJAUAN PUSTAKA}

Dalam upaya perlu dilakukan tinjauan pustaka atau literature review sebagai salah satu dari penerapan metode penelitian yang akan dilakukan. Diantaranya mengidentifikasikan kesenjangan (identify gaps), menghindari pembuatan ulang (reinventing the wheel), mengidentifikasikan metode yang pernah dilakukan, serta mengetahui orang lain yang spesialisasi dan area penelitian yang sama dibidang ini. Beberapa literature review tersebut adalah sebagai berikut:

\begin{tabular}{|l|l|l|l|}
\hline $\begin{array}{c}\text { Judul } \\
\text { Penelit } \\
\text { ian }\end{array}$ & Hasil & Identifikasi & Sumber \\
\hline $\begin{array}{l}\text { "Dashb } \\
\text { oard }\end{array}$ & $\begin{array}{l}\text { Sudah } \\
\text { banyak }\end{array}$ & $\begin{array}{l}\text { 1. } \\
\text { Belum } \\
\text { adanya }\end{array}$ & $\begin{array}{l}\text { Henderi } \\
(2007)\end{array}$ \\
\hline
\end{tabular}

\begin{tabular}{|c|c|c|c|}
\hline $\begin{array}{l}\text { Techno } \\
\text { logy: } \\
\text { Sistem } \\
\text { Evalua } \\
\text { si } \\
\text { Kinerja } \\
\text { Cyberc } \\
\text { orp } \\
2020 "\end{array}$ & $\begin{array}{l}\text { perusa } \\
\text { haan } \\
\text { yang } \\
\text { mulai } \\
\text { mengg } \\
\text { unakan } \\
\text { dashbo } \\
\text { ard } \\
\text { sebagai } \\
\text { indicat } \\
\text { or dari } \\
\text { sistem } \\
\text { evaluas } \\
\text { i } \\
\text { mandir } \\
\text { i. }\end{array}$ & $\begin{array}{l}\text { prototype. } \\
\text { 2. } \text { Belum } \\
\text { adanya } \\
\text { tools untuk } \\
\text { dashboard. }\end{array}$ & [1] \\
\hline $\begin{array}{l}\text { "Dashb } \\
\text { oardin } \\
g \\
\text { Inform } \\
\text { ation } \\
\text { System } \\
\text { For } \\
\text { The } \\
\text { Educati } \\
\text { on } \\
\text { Sector: } \\
\text { Applica } \\
\text { tion } \\
\text { and } \\
\text { Method } \\
\text { ologies } \\
\text { ". }\end{array}$ & $\begin{array}{l}\text { Menin } \\
\text { gkatny } \\
\text { a } \\
\text { pembu } \\
\text { atan } \\
\text { dashbo } \\
\text { arding } \\
\text { dengan } \\
\text { bahasa } \\
\text { pemro } \\
\text { graman } \\
\text { PHP } \\
\text { dan } \\
\text { membu } \\
\text { at front } \\
\text { office. } \\
\text { Sehing } \\
\text { ga } \\
\text { (DIS) } \\
\text { juga } \\
\text { mampu } \\
\text { menera } \\
\text { pkan } \\
\text { prinsip } \\
\text { dan } \\
\text { cara } \\
\text { kerja } \\
\text { yang } \\
\text { akurat. }\end{array}$ & $\begin{array}{ll}\text { 1. } & \text { Front } \\
\text { office } \\
\text { sebagai } \\
\text { interfac } \\
\text { e. } \\
\text { 2. } & \text { Belum } \\
\text { adanya } \\
\text { softwar } \\
e \\
\text { fussion } \\
\text { chart } \\
\text { sebagai } \\
\text { aplikasi } \\
\text { pembua } \\
\text { t grafik. }\end{array}$ & $\begin{array}{l}\text { Henderi } \\
\text { (2011) } \\
{[2]}\end{array}$ \\
\hline $\begin{array}{l}\text { "Peran } \\
\text { cangan } \\
\text { Aplikas } \\
\mathrm{i} \\
\text { Dashbo } \\
\text { ard } \\
\text { Inform } \\
\text { ation } \\
\text { System } \\
\text { Mengg }\end{array}$ & $\begin{array}{l}\text { Pimpin } \\
\text { an } \\
\text { dapat } \\
\text { menga } \\
\text { mbil } \\
\text { keputu } \\
\text { san } \\
\text { melalui } \\
\text { dashbo } \\
\text { ard }\end{array}$ & $\begin{array}{ll}\text { 1. } & \text { Meranc } \\
\text { ang } \\
\text { sebuah } \\
\text { sistem } \\
\text { informa } \\
\text { si } \\
\text { dashbo } \\
\text { ard } \\
\text { technol } \\
\text { ogy }\end{array}$ & $\begin{array}{l}\text { Henderi } \\
d k k . \\
(2012) \\
{[3]}\end{array}$ \\
\hline
\end{tabular}




\begin{tabular}{|c|c|c|c|c|}
\hline $\begin{array}{l}\text { unakan } \\
\text { Data } \\
\text { XML". }\end{array}$ & $\begin{array}{l}\text { karena } \\
\text { dapat } \\
\text { memon } \\
\text { itor } \\
\text { kinerja } \\
\text { perusa } \\
\text { haan. }\end{array}$ & & $\begin{array}{l}\text { dengan } \\
\text { visualis } \\
\text { asi } \\
\text { data. }\end{array}$ & \\
\hline $\begin{array}{l}\text { "Imple } \\
\text { mentasi } \\
\text { Dashbo } \\
\text { ard } \\
\text { Untuk } \\
\text { Memon } \\
\text { itor } \\
\text { Kinerja } \\
\text { Pegawa } \\
\text { i dan } \\
\text { Progra } \\
\text { m } \\
\text { Acara } \\
\text { di } \\
\text { Stasiun } \\
\text { Radio } \\
\text { Berbasi } \\
\text { s } \\
\text { Web". }\end{array}$ & $\begin{array}{l}\text { Dashb } \\
\text { oard } \\
\text { dapat } \\
\text { mengu } \\
\text { kur } \\
\text { kinerja } \\
\text { dari } \\
\text { setiap } \\
\text { pegawa } \\
\text { i } \\
\text { khusus } \\
\text { nya } \\
\text { penyiar }\end{array}$ & 1. & $\begin{array}{l}\text { Mengid } \\
\text { entifika } \\
\text { si pihak } \\
\text { stasiun } \\
\text { radio } \\
\text { akan } \\
\text { macam } \\
\text { bentuk } \\
\text { informa } \\
\text { si dari } \\
\text { berbaga } \\
\text { i } \\
\text { sumber } \\
\text { OLTP. }\end{array}$ & $\begin{array}{l}\text { Rizky } \\
\text { Dinal A } \\
(2010) \\
{[4]}\end{array}$ \\
\hline $\begin{array}{l}\text { "Imple } \\
\text { mentasi } \\
\text { Artifici } \\
\text { al } \\
\text { Inform } \\
\text { atics } \\
\text { pada } \\
\text { Sistem } \\
\text { Inform } \\
\text { asi } \\
\text { Kalend } \\
\text { er } \\
\text { Akade } \\
\text { mik } \\
\text { dalam } \\
\text { Penyeb } \\
\text { aran } \\
\text { Inform } \\
\text { asi di } \\
\text { Pergur } \\
\text { uan } \\
\text { Tinggi" } \\
\text {. }\end{array}$ & $\begin{array}{l}\text { Penera } \\
\text { pan ini } \\
\text { merupa } \\
\text { kan } \\
\text { bentuk } \\
\text { remind } \\
\text { er } \\
\text { setiap } \\
\text { kegiata } \\
\mathrm{n} \text { yang } \\
\text { telah } \\
\text { dijadw } \\
\text { alkan } \\
\text { secara } \\
\text { kompu } \\
\text { terisasi } \\
\text { kepada } \\
\text { seluruh } \\
\text { unsur } \\
\text { civitas } \\
\text { akade } \\
\text { mik } \\
\text { pergur } \\
\text { uan } \\
\text { tinggi. }\end{array}$ & 1. & $\begin{array}{l}\text { Meman } \\
\text { faatkan } \\
\text { infastru } \\
\text { ktur } \\
\text { jaringa } \\
\text { n } \\
\text { komput } \\
\text { er dan } \\
\text { fasilitas } \\
\text { email } \\
\text { yang } \\
\text { sudah } \\
\text { ada. }\end{array}$ & $\begin{array}{l}\text { Muham } \\
\text { ad } \\
\text { Yusup } \\
(2011) \\
{[5]}\end{array}$ \\
\hline
\end{tabular}

Berdasarkan dari 5 (lima) literature review yang ada di atas, dapat disimpulkan pula bahwa belum ada peneliti yang membahas "Implementasi Viewboard Dalam Mendukung Penyebaran Informasi Dengan Penyajian Artificial Informatics Pada Perguruan Tinggi". Oleh karena itu peneliti coba mengambil teknologi untuk menampilkan indicator berupa dashboard yang dirancang secara realtime dengan memanfaatkan fasilitas email.

\section{PEMECAHAN MASALAH}

Untuk mengatasi berbagai permasalahan di atas, maka diperlukan suatu sistem aplikasi dan teknologi untuk mengumpulkan, menyimpan, menganalisis, dan menyuguhkan akses data untuk membantu pimpinan dalam pengambilan keputusan. Sistem tersebut adalah Viewboard, merupakan sebuah tampilan visual dari informasi yang diperlukan untuk mencapai satu atau lebih tujuan, disatukan dan dikelompokkan pada sebuah panel, menjadi informasi yang diperlukan dan dapat dilihat secara sekilas.

Tampilan visual di sini mengandung pengertian bahwa penyajian informasi harus dirancang sebaik mungkin, sehingga mata manusia dapat menangkap informasi secara cepat dan otak manusia dapat memahami maknanya secara benar. Viewboard ditampilkan dalam satu monitor komputer penuh, yang berisikan informasi yang bersifat critical, agar kita dapat melihatnya dengan cepat, sehingga dengan melihat viewboard saja kita dapat mengetahui hal-hal yang perlu diketahui.

Penyajian informasi sebagai hasil dari output juga tidak hanya berbentuk laporan tabel dan data angka, melainkan dengan sentuhan karakteristik dari Artificial Informatics. Artificial Informatics adalah sebuah sistem informasi yang memiliki karakter dan kapabilitas seperti manusia dengan menggunakan PC dalam membantu menyelesaikan tugas sehari-hari (Rahardja, 2009) [6]. Oleh karena itu, hasil output yang disajikan menjadi tidak ada lagi data angka yang sedemikian berlimpah, dengan begitu dalam hal ini pimpinan dapat langsung mengidentifikasikan anomali-anomali dan memberikan keputusan berdasarkan informasi strategis yang diberikan oleh Viewboard. 


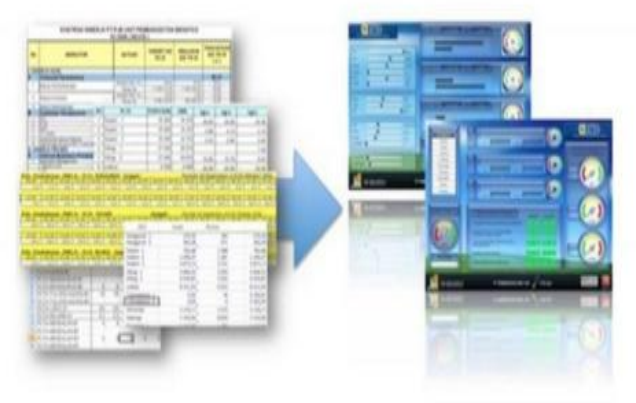

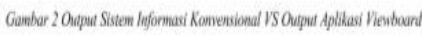

Dalam penyebaran informasinya, Pribadi Raharja dapat menggunakan email Rinfo sebagai jalur komunikasi resmi yang ada di lingkungan Perguruan Tinggi Raharja. Rinfo (Email Rahaja.Info) adalah layanan komunikasi email yang disediakan oleh Perguruan Tinggi Raharja untuk semua Pribadi Raharja, alat komunikasi utama dan paling vital untuk para Pribadi Raharja (Rahardja, 2014) [7]. Semua kegiatan yang dilakukan akan mustahil tanpa adanya Rinfo ini.

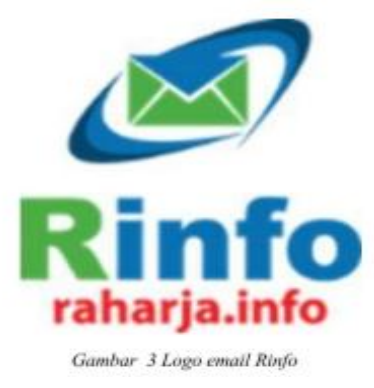

Jika Pribadi Raharja telah memiliki akun email Rinfo, akses menuju panel Viewboard dapat segera dilakukan dengan menerapkan konsep Single Sign On (selanjutnya disebut SSO). Konsep SSO dengan Rinfo ini akan sangat memudahkan Pribadi Raharja, karena dalam hal ini tidak diharuskan untuk lagi mengetikkan username ataupun password. Tidak lagi harus mengingat-ingat akun apa yang terdaftar di sana, hanya dengan sekali klik menggunakan email Rinfo semua akses dapat dicapai dengan mudahnya. Proses aktivasi pun tidak lagi membutuhkan peran admin, sistem Viewboard sendiri yang akan mengirimkan email konfirmasi sesaat setelah Pribadi Raharja login untuk yang pertama kalinya.

Untuk memudahkan penjabaran dari sistem Viewboard, maka dilakukan cara alternatif penggambaran sistem melalui alur flowchart. Di bawah ini merupakan alur flowchart dari sistem aplikasi Viewboard.

\section{Flowchart Login Viewboard}

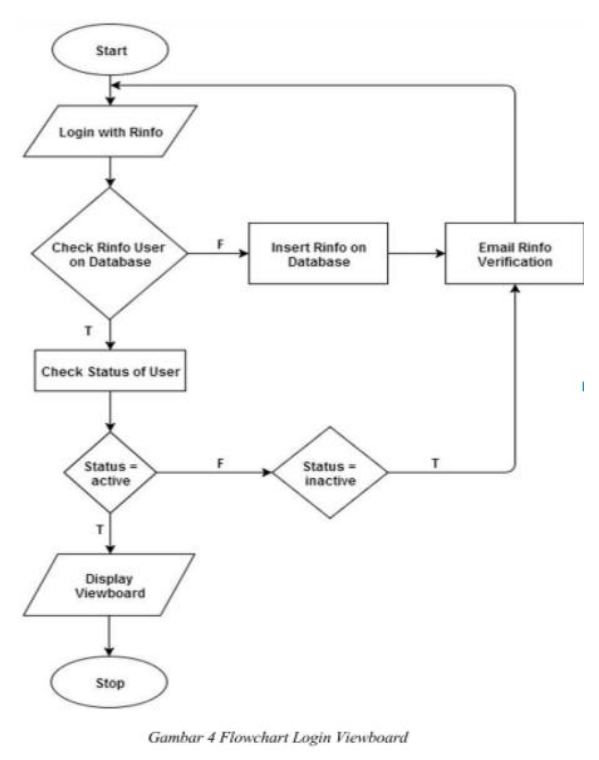

\section{IMPLEMENTASI}

$\begin{array}{rrr}\text { Viewboard } & \text { sendiri } & \text { telah } \\ \text { diimplementasikan pada } & \text { Perguruan } & \text { Tinggi }\end{array}$ Raharja dalam mendukung sistem penyebaran informasinya. Aplikasi Viewboard yang dikembangkan pada penelitian ini mempunyai keunggulan bila dibandingkan dengan pelaporan sistem informasi biasa karena memiliki ciri khas Artificial Informatics. Dengan karakteristik dari Artificial Informatics, penyajian informasi yang disampaikan lebih terkesan menarik daripada laporan yang hanya berupa data angka maupun tabel. Berikut akan dijelaskan beberapa contoh hasil implementasi dan uji coba aplikasi Viewboard berdasarkan data factual yang ada pada database Perguruan Tinggi Raharja sebagai tempat penelitian dan uji coba dilaksanakan.

1. Tampilan halaman login Viewboard Halaman login adalah halaman yang pertama kali muncul saat user membuka Viewboard. Pada halaman ini pengguna email Rinfo yakni, Pribadi Raharja saja yang memiliki akses masuk ke dalam panel Viewboard. 


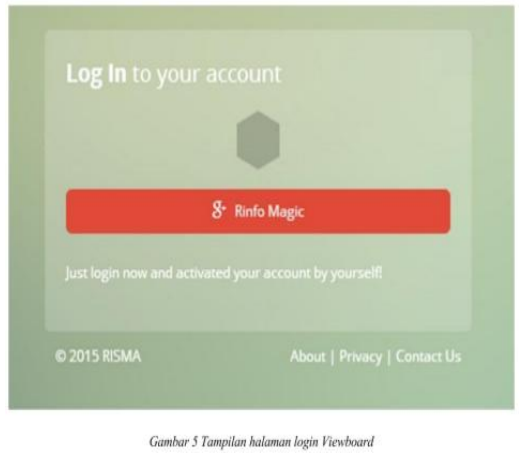

2. Email Verifikasi Rinfo

Email verifikasi ini hanya diberikan satu kali sesaat ketika Pribadi Raharja login untuk yang pertama kalinya. Email ini dikirimkan secara otomatis oleh sistem Viewboard sendiri untuk aktivasi akun tanpa melalui perantara admin.

3. Tampilan halaman panel Viewboard

Halaman panel ini hanya dapat diakses bagi Pribadi Raharja yang telah melakukan aktivasi melalui klik link email verifikasi yang diberikan otomatis oleh sistem Viewboard. Pada Viewboard tersajikan pelbagai informasi yang tidak hanya berupa data angka dan tabel saja. Melainkan terpaparkan informasi yang disajikan secara komunikatif oleh sistem, selayaknya manusia yang memiliki karakter.

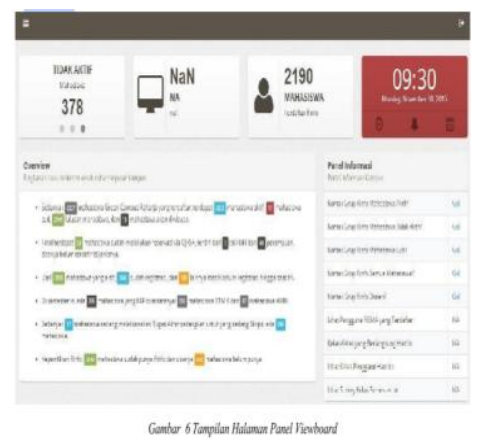

Tampak pada gambar enam, aplikasi Viewboard ini dapat menampilkan hasil pengolahan data/informasi yang aktual tentang kondisi status mahasiswa yang terdaftar di Perguruan Tinggi Raharja. Banyaknya perbandingan antara mahasiswa yang aktif semester dengan yang tidak aktif hingga mereka yang sedang cuti semester. Diinformasikan juga tentang status reservasi dari OJRS+ (sistem penjadwalan kuliah) dan mahasiswa yang registrasi semester. Perbandingan antara mahasiswa yang sedang KKP AMIK \& STMIK hingga Tugas Akhir maupun Skripsi. Serta informasi tentang status dari kepemilikan Email Rinfo terkini.

\section{LISTING PROGRAM}

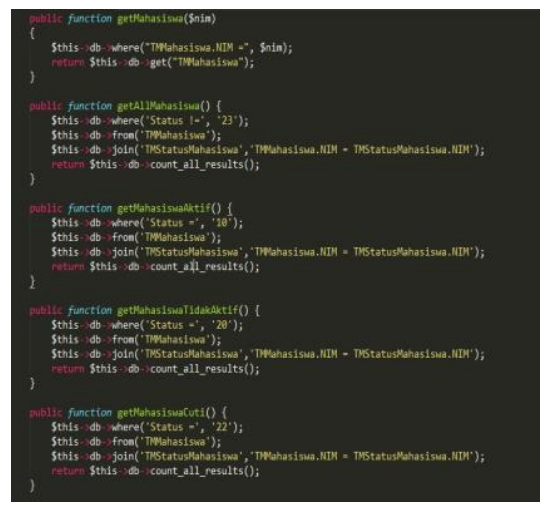

Gambar 7 Listing Model di Homepage Pada

Viewboard

\section{KESIMPULAN}

Hasil akhir dari pengujian dan implementasi menunjukkan bahwa Viewboard dapat menghasilkan dan menyajikan informasi dalam bentuk dashboarding, visual, factual, realtime, dan on line. Jenis dan tipe informasi yang dihasilkan oleh Viewboard merupakan bentuk dari ringkasan (overview) yang bersifat critical dan strategis. Penyajian informasi juga memiliki sifat karakteristik Artificial Informatics, sehingga mudah dipahami dan dipantau serta bisa mendukung dalam pengambilan keputusan. Hasil output yang disajikan menjadi tidak ada lagi data angka yang sedemikian berlimpah, dengan begitu dalam hal ini pimpinan dapat langsung mengidentifikasikan anomali-anomali dan memberikan keputusan berdasarkan informasi strategis yang diberikan oleh Viewboard.

\section{DAFTAR PUSTAKA}

[1] Henderi, Rahardja Untung, Sunarya Abas. Dashboard Technology: Sistem Evaluasi Kinerja Cybercorp 2020, Tangerang: Perguruan Tinggi Raharja, 2008. 
[2] Henderi, Rahardja Untung, Oktisa Qory, Hendri Muhamad. Dashboarding Information System For The Education Sector: Application and Methodologies, Tangerang: Perguruan Tinggi Raharja, 2011.

[3] Henderi, dkk. Perancangan Dashboard Information System Menggunakan XML. Tangerang. 2011.

[4] Rizky Dinal A. Implementasi Dashboard Untuk Memonitor Kinerja Pegawai dan Program Acara di Stasiun Radio Berbasis Web. Jakarta, 2010. Amikom, Yogyakarta.

[5] Yusup Muhamad, El Rayeb Augury, Rahayu Sri. Implementasi Artificial Informatics Pada Sistem Informasi Kalender Akademik Dalam Penyeberan Informasi di Perguruan Tinggi. Tangerang. 2011.

[6] Rahardja Untung. Artificial Informatics. Perguruan Tinggi Raharja, IEEE Transl, May 2009 [at the 4th IEEE Conference on Industrial Electronics and Applications Xi'an China, 2009].

[7] Rahardja Untung, Tiara Khanna, Taufik Wijaya Ray Indra. Penerapan Rinfo Sebagai Media Pendukung Untuk Proses Pembelajaran Pada Perguruan Tinggi Raharja. Tangerang. 